\title{
The earliest directly dated rock paintings from southern Africa: new AMS radiocarbon dates
}

\author{
Adelphine Bonneau ${ }^{1,2,3, *}$, David Pearce ${ }^{2}$, Peter Mitchell ${ }^{2,4}$, \\ Richard Staff ${ }^{5}$, Charles Arthur ${ }^{4}$, Lara Mallen ${ }^{2}$, Fiona Brock ${ }^{5,6}$ \\ $\&$ Tom Higham ${ }^{5}$
}

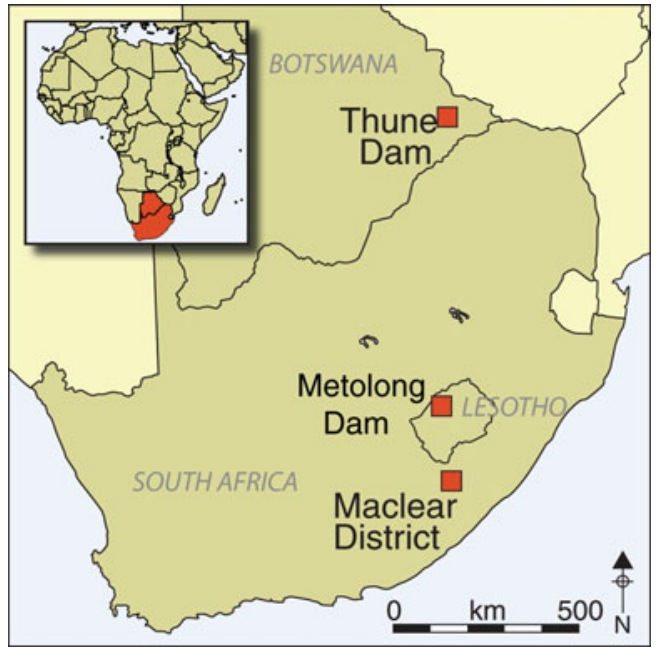

Rock art worldwide has proved extremely difficult to date directly. Here, the first radiocarbon dates for rock paintings in Botswana and Lesotho are presented, along with additional dates for Later Stone Age rock art in South Africa. The samples selected for dating were identified as carbon-blacks from short-lived organic materials, meaning that the sampled pigments and the paintings that they were used to produce must be of similar age. The results reveal that southern African hunter-gatherers were creating paintings on rockshelter walls as long ago as 5723-4420 cal BP in south-eastern Botswana: the oldest such evidence yet found in southern Africa.

Keywords: South Africa, Lesotho, Botswana, Later Stone Age, rock art, AMS radiocarbon dating

\section{Introduction}

Southern Africa is home to one of the world's largest and best-understood bodies of huntergatherer rock art. Comprising both engravings and paintings (Figure 1), it was produced by

1 Laboratoire Lux/Centre de recherche Géotop, Département des Sciences de la Terre et de l'atmosphère, Université du Québec à Montréal, CP 8888 Succursale Centre-Ville, Montréal, Québec H3C 3P8, Canada

2 Rock Art Research Institute, School of Geography, Archaeology and Environmental Studies, University of the Witwatersrand, 1 Jan Smuts Avenue, Johannesburg, 2050, South Africa

3 Centre interuniversitaire d'études sur les lettres, les arts et les traditions, Université du Québec à Montréal, CP 8888 Succursale Centre-Ville, Montréal, Québec H3C 3P8, Canada

4 Institute of Archaeology, University of Oxford, 36 Beaumont Street, Oxford OX1 2PG, UK

5 Research Laboratory for Archaeology and the History of Art, University of Oxford, South Parks Road, Oxford OXI $3 Q Y, U K$

6 Cranfield Forensic Institute, Cranfield University, Defence Academy of the United Kingdom, Shrivenham SN6 $8 L A, U K$

* Author for correspondence (E-mail: adelphine.bonneau@gmail.com) 


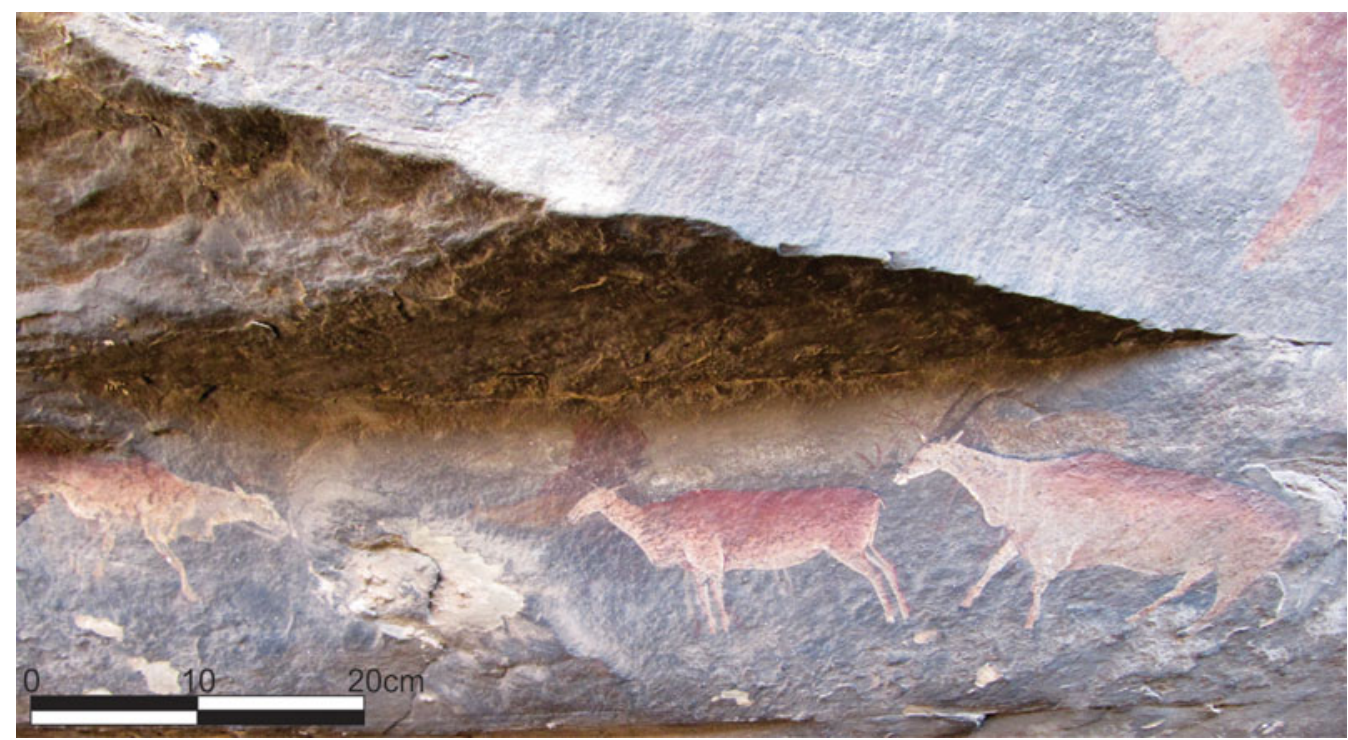

Figure 1. Example of fine-line Later Stone Age paintings (panel from RSA LAB1).

Later Stone Age (LSA) communities related to the contemporary Bushman (San) peoples of the Kalahari, and it is their ethnography, along with accounts obtained from Bushman informants in the late nineteenth century, that provides the basis for its understanding (Lewis-Williams \& Pearce 2004). Research over the past 40 years has shown that the art is most productively and comprehensively explained as the material expression of the powers of ritual specialists (shamans) and of the wider cosmology within which those powers were exercised, often in altered states of consciousness (trance) (Lewis-Williams 1981; LewisWilliams \& Pearce 2004, 2015). This research in southern Africa has influenced rock art studies around the world (e.g. Whitley 1998; Lewis-Williams 2002).

It has long been clear that LSA rock art was implicated in the social and economic lives of its makers (Lewis-Williams 1982), but researchers have encountered persistent difficulties in linking the parietal rock art to the excavated components of the archaeological record, and in exploring temporal variability within the art itself (e.g. Mazel \& Watchman 2003; Mazel 2009a). The reason for this is straightforward: rock art around the world is extremely difficult to date directly. Instances of paintings or engravings found within datable archaeological deposits in southern Africa are exceptionally rare (Wendt 1976; Mazel 1993, 1996; Walker 1995; Jerardino \& Swanepoel 1999). Most attempts at developing a chronological framework have therefore emphasised alternative strategies and been applied almost wholly to paintings. Stylistic sequences-with or without inferences drawn from situations where one image overlies another-remain contested however, while the content of the art (which sometimes includes imagery with chronological associations, such as cattle, sheep, horses or Europeans) sets only very broad time constraints (Mazel 2009a).

So far, efforts at directly dating images surviving on rockshelter walls have been limited. Early in the development of accelerator mass spectrometry (AMS) radiocarbon dating, a single result was obtained for a painting in the Cederberg Mountains of the Western Cape 
Province, South Africa (Van der Merwe et al. 1987). Subsequently, attention shifted to the Drakensberg Escarpment of KwaZulu-Natal, South Africa, where eight dates were obtained on weathering layers composed of calcium oxalates present above or below painted images at five sites (Mazel \& Watchman 1997, 2003). Two dates were obtained on overlying layers, calibrated to between approximately 1000 and $2000 \mathrm{BP}$; six dates on underlying layers came to between approximately 2000 and 4000 BP. These results nevertheless offer only termini ante or post quos for the art, although a ninth date $\left(330 \pm 90{ }^{14} \mathrm{C}\right.$ years BP, $507-297 \mathrm{cal}$ BP) _ from a plant fibre embedded within paint at another site in the same region-may perhaps directly date the painting in question (Mazel \& Watchman 1997).

Attempts at directly dating LSA rock paintings have thus been few in number and restricted in spatial extent. This leaves their chronology poorly constrained compared to, for instance, Upper Palaeolithic paintings in Western Europe (Pettitt \& Pike 2007) or those of the Kimberley region of Australia (Aubert 2012). In this article, we report on the direct AMS radiocarbon dating of rock paintings at 14 sites in three regions of southern Africa: the Thune Dam area of south-eastern Botswana $(n=3)$, the Metolong Dam catchment of western Lesotho $(\mathrm{n}=5)$ and the Maclear District of South Africa's Eastern Cape Province $(n=6)$ (Figure 2).

\section{Rock art sites}

\section{The Thune Dam, Botswana}

The Thune Dam is located in the Kalahari Desert, near the town of Mathathane, approximately $20 \mathrm{~km}$ west of the South African border and $500 \mathrm{~km}$ north-east of Gaborone, the capital of Botswana. Forty archaeological sites are present in a narrow band about $35 \mathrm{~km}$ long and $5 \mathrm{~km}$ wide, along the Thune River. Among them, six rock art sites have been flooded by the construction of a dam, and 18 others would be at risk in the event of exceptional floods. All 24 sites were recorded and some were excavated, revealing some LSA artefacts (Walker 2009).

Rock art at the sites includes finger paintings and LSA fine-line tradition paintings (Figure 3), but, interestingly, few superimpositions are visible. Distinctive regional representations such as giraffe and fish are present. The most important representations at these sites are paintings of sheep, as these constitute the only such example currently known in Botswana (Walker 2009). The finger paintings are peripheral to, or superimposed upon, LSA paintings and thus appear to have been made at a later period. Three of the 24 sites were sampled for dating: TD2, TD12 and TD21.

\section{The Phuthiatsana Valley, Lesotho}

The Phuthiatsana River Valley is located approximately $30 \mathrm{~km}$ east of Maseru, the capital of Lesotho. From 1979-1982, this valley and three other areas were examined by Lucas Smits and his team in order to record rock art sites as part of the 'Analysis of Rock Art of Lesotho' (ARAL) project (Smits 1983). In total, 493 sites were recorded, 259 of which were in the Phuthiatsana Valley.

(C) Antiquity Publications Ltd, 2017 


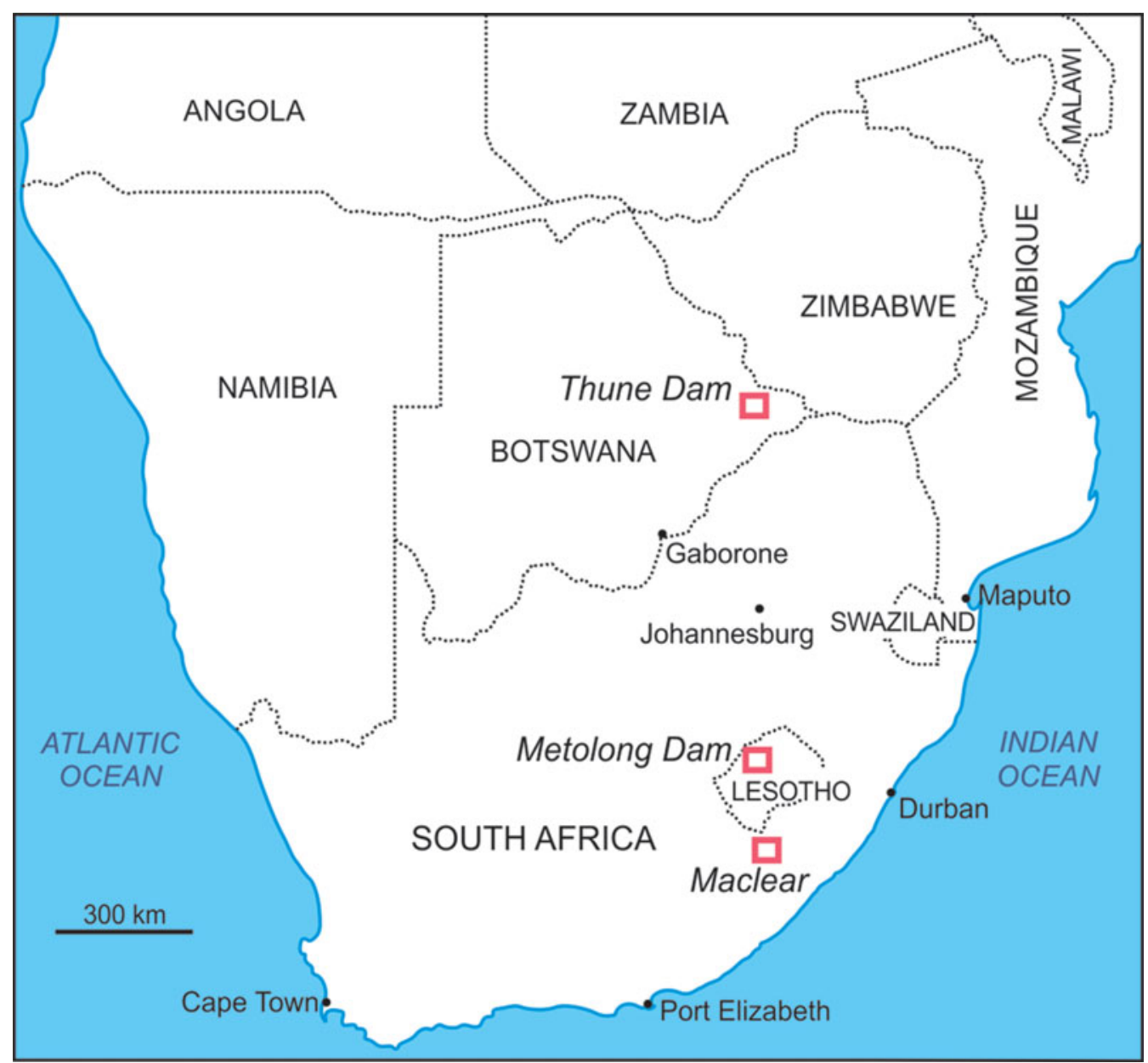

Figure 2. Map of southern Africa, showing locations of rock art research areas studied in the current project.

In 1989 and 1990, excavations and survey were conducted in the Phuthiatsana Valley by Peter Mitchell. These were resumed in 2008 ahead of the construction of a dam that has since flooded several of the sites present there. Excavations and survey documented evidence of past Middle Stone Age and LSA occupations, as well as more recent activity by Sothospeaking farming communities (Mitchell 1994; Mitchell \& Whitelaw 2005; Mitchell \& Arthur 2010, 2014).

The Metolong catchment, where the dam has been built, is only a very small section of the total Phuthiatsana Valley. Within it, 29 rock art sites were identified and recorded (Mallen 2011). Some panels were removed from selected sites for long-term preservation and (hopefully) display. Five separate painting traditions have been identified in the Metolong Dam area; the two most common are the LSA fine-line tradition (Figure 4) and the Basotho tradition. Ochre smears, finger-painted figures and figures of unknown traditions complete the list (Mallen 2011). Five sites (ARAL171, ARAL172, ARAL175, ARAL249 and ARAL252) were sampled for dating. 


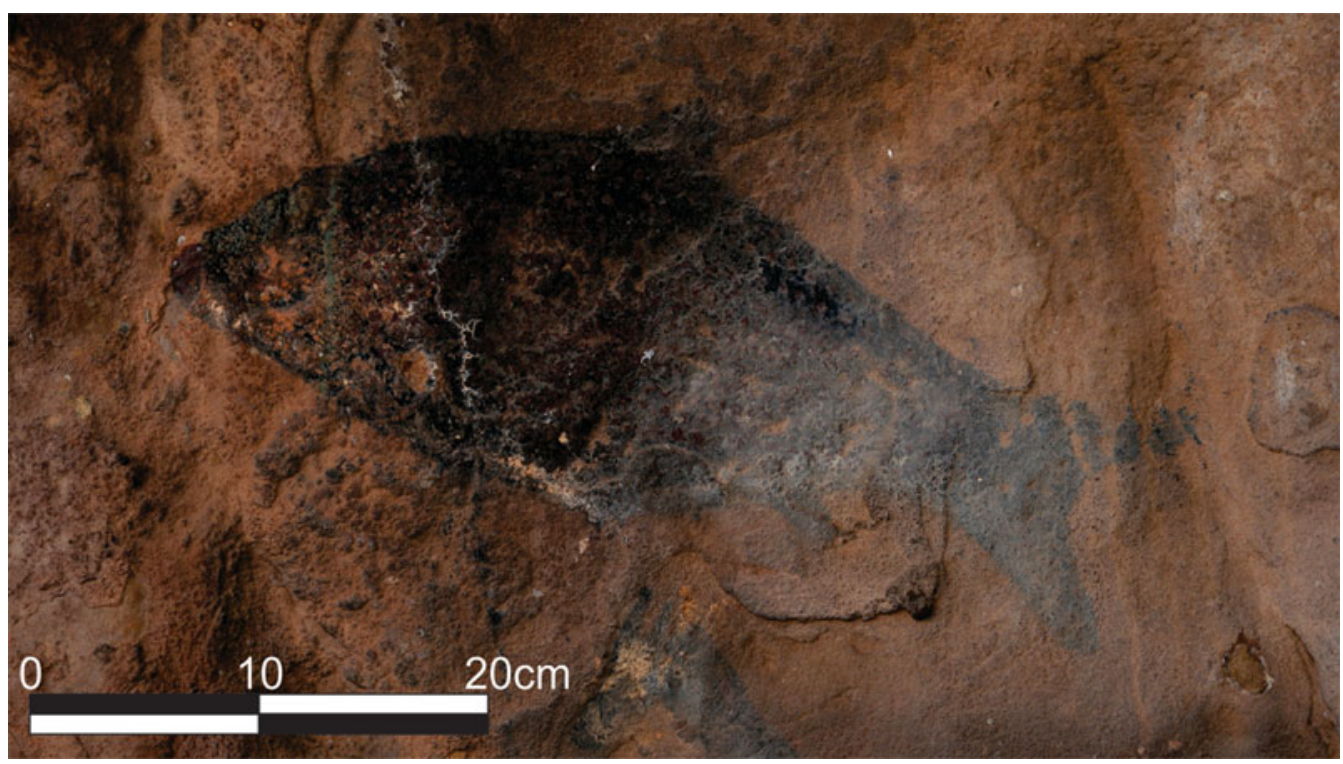

Figure 3. Painting of a fish of Later Stone Age tradition in the Thune Valley, Botswana (panel from TD12).

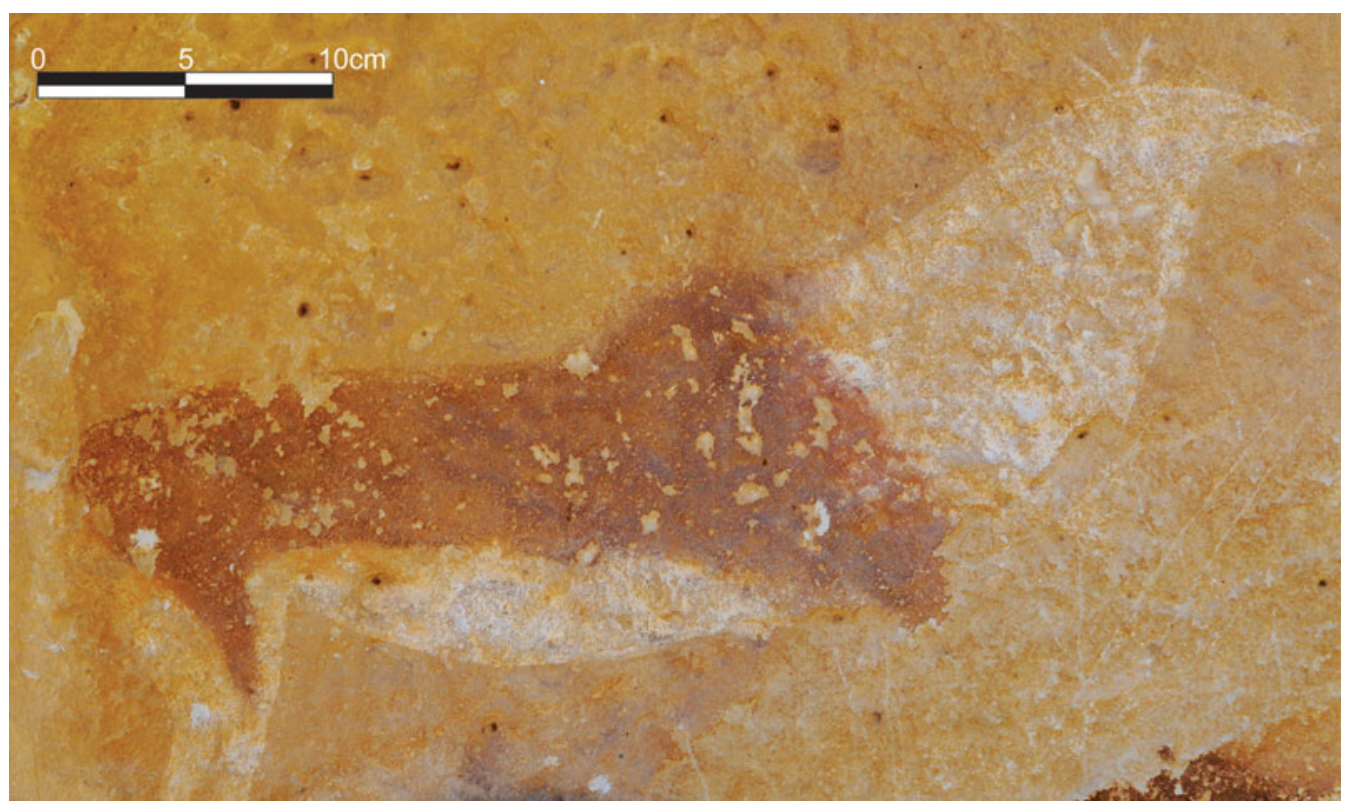

Figure 4. Painting of an eland of Later Stone Age tradition in the Phuthiatsana Valley, Lesotho (panel from ARAL180).

\section{The Maclear District, South Africa}

The Maclear District is located around the town of Maclear, in the Eastern Cape Province, South Africa. About 300 rock art sites have been recorded in this area. The district is part of a larger region known as 'Nomansland' by the former colonial administration (Blundell (C) Antiquity Publications Ltd, 2017 


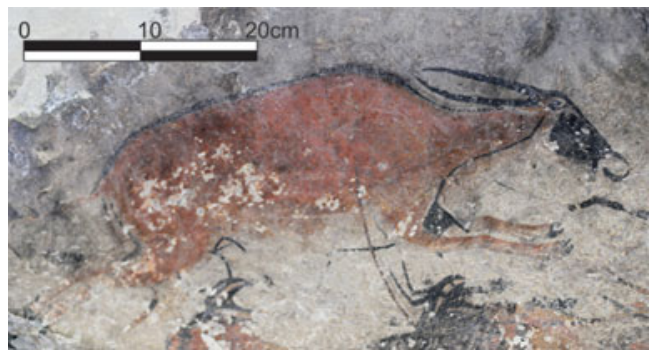

Figure 5. Paintings of an eland and human figures of Later Stone Age tradition in the Maclear District, South Africa (panel from RSA TYN2).

2004). Although very few dates from archaeological deposits are available for Nomansland, those that are give evidence of an occupation by hunter-gatherers from at least 22000 years ago to the colonial period (Opperman \& Heydenrych 1990).

Six rock art sites were sampled for dating: RSA CHA1, RSA FRE4, RSA LAB1 (also called Storm Shelter), RSA LAB7, RSA PRH1 and RSA TYN2. The paintings studied are all of the LSA tradition, with fine-lined paintings and colour gradients (Figure 5).

None of these sites has been excavated, so no other archaeological material is thus available for comparison with the paintings or to give an idea of possible periods of occupation.

\section{Methods}

Rock art is extremely difficult to date reliably by AMS. We have therefore developed rigorous protocols for the field collection of paint samples, characterisation of pigment samples and preparation for radiocarbon dating. These include a two-stage sampling strategy to increase the success rate for dating samples.

In the first stage, we collected small samples for characterisation. Approximately $0.5 \mathrm{~mm}^{2}$ samples of paint were collected from potentially datable paintings. The samples were analysed unprepared and in cross-section using light microscopy, scanning electron microscopy-energy dispersive X-ray spectroscopy (SEM-EDS), and Raman and Fourier transform infrared (FTIR) spectroscopies to determine morphology and elemental and molecular composition (Figure 6, see details in online supplementary material (OSM) and in Bonneau et al. in press). Results of these analyses informed decisions as to which paintings should be sampled for AMS radiocarbon dating, and we selected those samples that were most likely to be successfully radiocarbon dated.

In all but two cases, this characterisation confirmed that the samples dated were carbonblacks; in other words, the incomplete combustion of organic compounds such as fat or resin. This means that the carbon that was dated derived from short-lived organic materials that are unlikely to have been significantly older than the date of manufacture of the paint. This is important because it overcomes the frequent criticism that charcoal used in paint may be significantly older than the painting event in which it was used. We have, considering the errors and uncertainties inherent in radiocarbon dating, therefore dated the time of paint manufacture. 


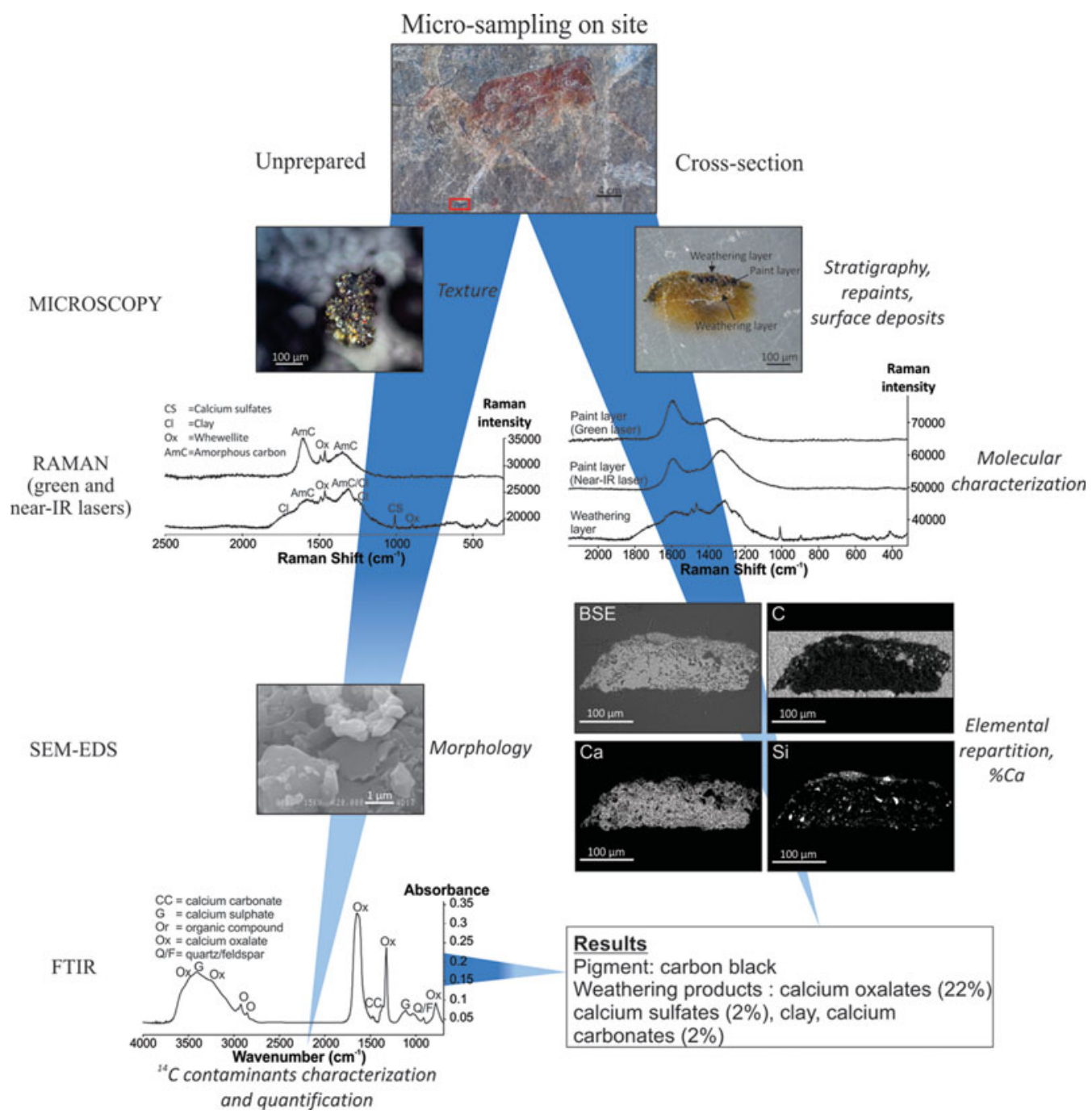

Figure 6. Example of characterisation of a black paint (instrument names are depicted in capitals, and results in italics).

We prepared samples for AMS dating using a modified acid-base-acid procedure that is designed to remove calcium carbonates and calcium oxalates (which are radiocarbon contaminants) from the pigments. We tested several methods to find the most suitable approach. We used $1 \mathrm{M} \mathrm{HCl}$ for $20-60$ minutes at $80^{\circ} \mathrm{C}$, followed by routine $\mathrm{NaOH}$ $(0.1 \mathrm{M})$ and a further $\mathrm{HCl}$ step $(1 \mathrm{M})$ for $30-60$ minutes at $80^{\circ} \mathrm{C}$, with ultrapure Milli$\mathrm{Q}^{\mathrm{TM}}$ water rinsing in between the steps. This approach was modified for different samples depending on the sample size and characterisation results. The pigments were freeze-dried and FTIR analysis was conducted to confirm that previously identified contaminants had been eliminated prior to further preparation. Samples were then combusted to $\mathrm{CO}_{2}$ in an EA-IRMS, and graphitised before AMS dating. Graphite samples were uniformly small $(<0.5-1 \mathrm{mg} \mathrm{C})$, and were analysed with standards and backgrounds of a similar size to the (C) Antiquity Publications Ltd, 2017 
archaeological samples of unknown age. The methods used are described in detail in the OSM and in Bonneau et al. (in press).

\section{Results and discussion}

Little previous research has been conducted on the rock art of Botswana's Central District. Our samples came from sites in its south-eastern corner that were flooded in 2013 by the construction of the Thune Dam. We succeeded in producing nine dates from three sites, although four dates were obtained on $<100 \mu \mathrm{g}$ of carbon and thus need to be interpreted with care. These are the first direct radiocarbon dates on rock paintings in Botswana. All of the paintings are unequivocally attributable to the fine-line LSA tradition when considering the images and the techniques used by the artists.

The samples from Lesotho came from rock art sites in the western lowlands, in the section of the Phuthiatsana Valley that was flooded in early 2014 following impoundment of the Metolong Dam. We successfully dated eight paintings from three sites; four more samples from two additional sites should be treated with caution, as they were obtained on $<100 \mu \mathrm{g}$ of carbon and, as a result, two of them have unacceptably large uncertainties. These are, nevertheless, the first direct radiocarbon dates for rock paintings in Lesotho. While some of the paintings present at Metolong can be attributed to the area's present-day Basotho population or to groups of multi-ethnic origin living in the wider region during the nineteenth century, all of the paintings that we have dated again belong to the fine-line LSA tradition (Mallen 2011).

In contrast to the other regions, the Maclear District of South Africa has long been a major centre for interpretative rock art research. It is situated towards the southern end of the Drakensberg Range. Unlike the other two areas where we have worked, rock art sites here are not endangered by dams. Our research to characterise and date the paints used in rock art began on a series of painted, naturally spalled flakes (Bonneau et al. 2011, 2012). We have since produced 22 dates from six sites. One further sample failed due to the continued presence of calcium oxalates after pre-treatment. Apart from one painting at RSA LAB7, all of the dated paintings clearly belong to the fine-line LSA tradition. Further details of all of the sites and samples are given in the OSM.

Table 1 summarises our results as calibrated using the southern hemisphere SHCal13 calibration curve and OxCal v4.2 software (Bronk Ramsey 2009; Hogg et al. 2013). Although some measurement uncertainties are large (because of very small sample sizes), our results, even in these cases, are informative given the lack of any previous chronometrically based rock art dating for these regions. In western Lesotho, for example, the bulk of the paintings dated were created in the last 1000 years BP (Table 1).

Our study has produced several significant results. Firstly, it demonstrates that the protocol used previously at Maclear on painted flakes is robust and can be successfully extended to in situ parietal paintings, as well as to other regions of southern Africa where paint preparation, geology, weathering conditions and contaminants may vary. It is therefore probable that the same protocol could be used anywhere that carbon-based paints are found. The strength of this protocol is that it provides a detailed characterisation of the paint, which makes it possible to adjust sample collection methods and chemical 
Table 1. AMS radiocarbon ages of rock paintings from Thune Dam (Botswana), Metolong Dam (Lesotho) and Maclear District (South Africa). Samples are listed in chronological order within each research area. Calibrated dates were obtained using OxCal v4.2 (Bronk Ramsey 2009) and the SHCal13 calibration curve (Hogg et al. 2013), and are expressed at $95.4 \%$ confidence. Further details of each sample and its calibration are provided in the OSM.

\begin{tabular}{lccc}
\hline $\begin{array}{l}\text { Sample } \\
\text { identification }\end{array}$ & $\begin{array}{c}\text { AMS laboratory } \\
\text { code }\end{array}$ & $\begin{array}{c}\text { Conventional }{ }^{14} \mathrm{C} \\
\text { age BP }( \pm 1 \sigma)\end{array}$ & $\begin{array}{c}\text { Calibrated age BP } \\
(95.4 \% \text { confidence })\end{array}$ \\
\hline
\end{tabular}

\section{Thune Dam, Botswana}

TD2-2012-1

TD2-2012-19

TD12-2012-7

TD12-2012-9

TD21-2012-2

TD21-2012-3

TD2-2012-21

TD12-2012-8

TD12-2012-6

Metolong Dam, Lesotho

ARAL175-C1

ARAL175-C2

ARAL175-2012-2

ARAL175-C2

ARAL175-2012-3

ARAL175-2012-1

ARAL249-2012-1

ARAL171-C1

ARAL172-C1

ARAL252-C4

ARAL-252-C2

ARAL-252-C1

\section{Maclear District, South Africa}

LAB7-2013-C2

LAB7-2013-C1

FRE4-2013-C7

PRH1-2013-C2

PRH1-2013-C1

FRE4-2013-C6

FRE4-2013-C4

FRE4-2013-C3

FRE4-2013-C8

LAB1-2013-C3

LAB1-C2

TYN2-C6

TYN2-C5

LAB1-C1

TYN2 RP/2009/003/13

TYN2-C3

TYN2 RP/2009/003/29

TYN2 RP/2009/003/14

OxA-X-2555-49
OxA-X-2555-48
OxA-X-2555-45
OxA-X-2543-6
OxA-X-2555-44
OxA-X-2555-43
OxA-X-2555-47
OxA-29182
OxA-X-2555-46

OxA-X-2470-49

OxA-X-2470-48

OxA-X-2555-39

OxA-X-2495-27

OxA-X-2555-26

OxA-X-2555-40

OxA-X-2555-24

OxA-X-2470-50

OxA-X-2479-37

OxA-X-2479-36

OxA-X-2479-35

OxA-X-2479-34

OxA-28978

OxA-28977

OxA-X-2555-19

OxA-29186

OxA-28980

OxA-X-2555-20

OxA-X-2555-21

OxA-X-2555-22

OxA-X-2555-18

OxA-X-2555-17

OxA-25961

OxA-25966

OxA-25965

OxA-25960

OxA-X-2370-29

OxA-25964

OxA-X-2370-31

OxA-X-2370-30

$$
\begin{gathered}
1250 \pm 80 \\
2130 \pm 90 \\
2500 \pm 100 \\
2580 \pm 390 \\
2580 \pm 130 \\
2630 \pm 230 \\
2960 \pm 160 \\
3060 \pm 30 \\
4500 \pm 260
\end{gathered}
$$

$$
\begin{gathered}
300 \pm 65 \\
390 \pm 70 \\
410 \pm 130 \\
470 \pm 90 \\
575 \pm 75 \\
760 \pm 120 \\
770 \pm 90 \\
1210 \pm 90 \\
1700 \pm 310 \\
2640 \pm 390 \\
5300 \pm 1000 \\
5700 \pm 2000
\end{gathered}
$$

$\begin{array}{cc}124 \pm 23 & \text { 254-present } \\ 147 \pm 23 & 263 \text {-present } \\ 290 \pm 90 & 494-\text { present } \\ 308 \pm 35 & 452-155 \\ 447 \pm 23 & 509-338 \\ 510 \pm 90 & 641-318 \\ 770 \pm 100 & 903-531 \\ 1160 \pm 140 & 1297-768 \\ 1420 \pm 140 & 1561-977 \\ 1530 \pm 90 & 1585-1189 \\ 1620 \pm 90 & 1700-1305 \\ 1900 \pm 90 & 2002-1586 \\ 1940 \pm 90 & 2050-1607 \\ 2040 \pm 120 & 2308-1705 \\ 2072 \pm 28 & 2081-1919 \\ 2080 \pm 90 & 2306-1754 \\ 2083 \pm 32 & 2093-1920 \\ 2100 \pm 40 & 2148-1926\end{array}$

$1276-962$
$2320-1878$
$2754-2332$
$3593-1712$
$2923-2327$
$3325-2109$
$3448-2751$
$3343-3077$
$5723-4420$

495-12

516-291

635-present

630-300

664-460

905-518

897-540

1274-927

2326-965

3691-1748

9003-4177

13579-1591

254-present

263-present

452-155

509-338

641-318

1297-768

1561-977

1585-1189

$1700-1305$

(C) Antiquity Publications Ltd, 2017 
Table 1. continued.

\begin{tabular}{llcc}
\hline $\begin{array}{l}\text { Sample } \\
\text { identification }\end{array}$ & $\begin{array}{c}\text { AMS laboratory } \\
\text { code }\end{array}$ & $\begin{array}{c}\text { Conventional }{ }^{14} \mathrm{C} \\
\text { age BP }( \pm 1 \sigma)\end{array}$ & $\begin{array}{c}\text { Calibrated age BP } \\
(\mathbf{9 5 . 4 \%} \text { confidence })\end{array}$ \\
\hline TYN2-C7 & OxA-25967 & $2290 \pm 110$ & $2699-1941$ \\
TYN2-C1 & OxA-25962 & $2390 \pm 140$ & $2748-2060$ \\
CHA1-C1 & OxA-X-2590-20 & $2590 \pm 110$ & $2848-2352$ \\
LAB1-2013-C5 & OxA-X-2555-16 & $2690 \pm 100$ & $2998-2381$ \\
\hline
\end{tabular}

pre-treatment to ensure the removal of any contaminants. Knowing the paint's composition also allows for better interpretation of dates (see Methods section).

Secondly, we have established that southern African hunter-gatherers were creating images on rockshelter walls as long ago as 5723-4420 cal BP in south-eastern Botswana, 2326-965 cal BP in western Lesotho and 2998-2381 cal BP in the Maclear District of South Africa (all calibrated ages are given at $95.4 \%$ confidence). We are confident that these dates reflect the date of paint manufacture according to a characterisation process that identifies black paintings as being composed of carbon-blacks. The older of the dates from site TD12, in Botswana, currently provides the oldest evidence for extant painting on rockshelter walls anywhere in southern Africa, although we note the presence of spalls with paint at two sites in the Matopos Hills, Zimbabwe, found in stratified contexts dating to the early to mid-Holocene (Walker 1995). Moreover, our study reveals the remarkable time-depth of painting on individual rockshelter walls, with two sites in Botswana (TD2 and TD12) providing a chronological range of between two and three millennia.

Thirdly, in each of our research areas, the direct radiocarbon dating of painted images opens up the opportunity for developing a chronometrically grounded approach to diversity and change within LSA rock art. As so much is known about the meaning of LSA rock art, these chronological changes should be understood in social terms (see Mazel 2009b for an example of this approach in the northern Drakensberg).

Fourthly, our results allow us to start developing a dialogue between the record of huntergatherer activity preserved in paint and that preserved in archaeological deposits. In the case of Lesotho's Metolong Dam catchment, for example, previous work there and in the wider Phuthiatsana Basin struggled to identify hunter-gatherer sites dating to the second half of the Holocene, and completely failed to locate any at all for the period 5600-700 cal BP (Mitchell 1994), despite their presence in an area with a very similar environment directly across the Caledon River in South Africa (Wadley 1995). Our results (from ARAL171 and, more cautiously, ARAL172) now show that hunter-gatherers were present for at least part of this period, implying that faulty survey methods and/or post-depositional changes to the region's landscape or to specific site stratigraphies have hindered the detection of in situ archaeological deposits.

Previous research in the northern Drakensberg region of South Africa, which dated oxalate crusts above surviving rock paintings, indicated that the practice of painting rockshelter walls began there more than 2000-3000 years ago. Our direct dating of carbonbased black pigments now establishes that paintings were made in the southern Drakensberg region at least as long ago as 2998-2381 cal BP, and that the practice of painting on 
rockshelter walls is up to 2000 years older than this in Botswana. Meanwhile, we have shown that LSA rock paintings can be directly dated using AMS radiocarbon technology, and that the results obtained can contribute meaningfully to wider archaeological debates. These techniques should also prove useful in chronological studies of rock art in other parts of the world, including the only three sites - all in Lesotho-for which specific interpretations of individual paintings were provided by a Bushman informant from a community in which rock art was still being produced (McGranaghan et al. 2013).

\section{Acknowledgements}

This project was funded by the South African National Research Foundation (to Pearce), the United Kingdom's Natural Environment Research Council (to Mitchell; NERC 2011/2/4 and NERC 2013/2/11), the French Institute in South Africa (to Bonneau and Pearce), and the Social Sciences and Humanities Research Council of Canada (to Bonneau), the Fonds de Recherche Québécois Société et Culture (to Bonneau), the Centre interuniversitaire d'Etudes sur les Lettres, les Arts et les Traditions (to Bonneau) and the Université du Québec à Montréal (to Bonneau). We are grateful to landowners and local communities for allowing us to work on their properties or in their territories. Bonneau particularly wishes to thank Daniel Arsenault and Michel Lamothe for their help and advice, Michelle Laithier for her help with the figures, and the Laboratoire de Microanalyse (Université Laval) and the Laboratoire de Caractérisation des Matériaux (Université de Montréal) for permission to use their equipment. Jess Meyer photographed the Lesotho sites, including supplementary Figures S6, S8, S10, S12 and S14. We thank David Whitley and Aaron Mazel for comments on the manuscript.

\section{Supplementary material}

To view supplementary material for this article, please visit http://doi.org/10.15184/aqy. 2016.271

\section{References}

Aubert, M. 2012. A review of rock art dating in the Kimberley, Western Australia. Journal of Archaeological Science 39: 573-77. https://doi.org/10.1016/j.jas.2011.11.009

Blundell, G. 2004. Nqabayo's Nomansland: San rock art and the somatic past. Uppsala: Uppsala University Press.

Bonneau, A., F. Brock, T.F.G. Higham, D.G. Pearce \& A.M. Pollard. 2011. An improved pretreatment protocol for radiocarbon dating black pigments in San rock art. Radiocarbon 53: 419-28. https://doi.org/10.1017/S003382220003455X

Bonneau, A., D.G. Pearce \& A.M. Pollard. 2012. A multi-technique characterization and provenance study of the pigments used in San rock art, South Africa. Journal of Archaeological Science 39: 287-94. https://doi.org/10.1016/j.jas.2011.09.011

Bonneau, A., R.A. Staff, T.F.G. Higham, F. Brock, D.G. Pearce \& P.J. Mitchell. In press. Successfully dating rock art in southern Africa using improved sampling methods and new characterization and pre-treatment protocols. Radiocarbon.

https://doi.org/10.1017/RDC.2016.69
Bronk Ramsey, C. 2009. Bayesian analysis of radiocarbon dates. Radiocarbon 51: 337-60. https://doi.org/10.1017/S0033822200033865

Hogg, A.G., H. Quan, P.G. Blackwell, N. Mu, C.E. Buck, T.P. Guilderson, T.J. Heaton, J.G. Palmer, P.J. Reimer, R.W. Reimer, C.S.M. Turney \& S.R.H. Zimmerman. 2013. SHCal13 southern hemisphere calibration curve, 0-50,000 years cal BP. Radiocarbon 55: 1889-903. https://doi.org/10.2458/azu_js_rc.55.16783

Jerardino, A. \& N. Swanepoel. 1999. Painted slabs from excavations at Steenbokfontein Cave: implications for past and future research. Current Anthropology 40: 542-48. https://doi.org/10.1086/200051

LeWIs-Williams, J.D. 1981. Believing and seeing: symbolic meanings in southern San rock paintings. London: Academic.

- 1982. The economic and social context of southern San rock art. Current Anthropology 23: 429-49. https://doi.org/10.1086/202871

- 2002. The mind in the cave: consciousness and the origins of art. London: Thames \& Hudson.

(C) Antiquity Publications Ltd, 2017 
Lewis-Williams, J.D. \& D.G. Pearce. 2004. San spirituality: roots, expression, and social consequences. Walnut Creek (CA): AltaMira.

- 2015. San rock art: evidence and argument. Antiquity 89: 732-39. https://doi.org/10.15184/aqy.2014.51

Mallen, L. 2011. Phase 2: rock art recording and interpretation. Unpublished report prepared for the Commissioner for Water, Government of Lesotho.

Mazel, A.D. 1993. Rock art and Natal Drakensberg hunter-gatherer history: a reply to Dowson. Antiquity 67: 889-92. https://doi.org/10.1017/S0003598X00063912

- 1996. Maqonqo Shelter: the excavation of Holocene deposits in the eastern Biggarsberg, Thukela Basin, South Africa. Natal Museum Journal of Humanities 8: 1-39.

-2009 a. Images in time: advances in the dating of Maloti-Drakensberg rock art since the 1970s, in P.J. Mitchell \& B.W. Smith (ed.) The eland's people: new perspectives in the rock art of the Maloti-Drakensberg Bushmen. Essays in memory of Patricia Vinnicombe: 81-97. Johannesburg: Witwatersrand University Press.

- 2009b. Unsettled times: shaded polychrome paintings and hunter-gatherer history in the southeastern mountains of southern Africa. Southern African Humanities 21: 85-115.

Mazel, A.D. \& A.L. Watchman. 1997. Accelerator radiocarbon dating of Natal Drakensberg paintings: results and implications. Antiquity 71: 445-49. https://doi.org/10.1017/S0003598X00085069

-2003 . Dating rock paintings in the uKhahlamba-Drakensberg and the Biggarsberg, KwaZulu-Natal, South Africa. Southern African Humanities 15: 59-73.

McGranaghan, M., S. Challis \& J.D. Lewis-Williams. 2013. Joseph Millerd Orpen's 'A glimpse into the mythology of the Maluti Bushmen': a contextual introduction and republished text. Southern African Humanities 25: 137-66.

Mitchell, P.J. 1994. The archaeology of the Phuthiatsana-ea-Thaba Bosiu Basin, Lesotho, southern Africa: changes in Later Stone Age regional demography. Antiquity 68: 83-96. https://doi.org/10.1017/S0003598X00046226
Mitchell, P.J. \& C. Arthur. 2010. Archaeological fieldwork in the Metolong Dam Catchment, Lesotho, 2008-10. Nyame Akuma 74: 51-62.

- 2014. Ha Makotoko: Later Stone Age occupation across the Pleistocene/Holocene transition in western Lesotho. Journal of African Archaeology 12: 205-32. https://doi.org/10.3213/2191-5784-10255

Mitchell, P. \& G. Whitelaw. 2005. The archaeology of southernmost Africa from c. $2000 \mathrm{BP}$ to the early 1800s: a review of recent research. Journal of African History 46: 209-41. https://doi.org/10.1017/S0021853705000770

Opperman, H. \& B. Heydenrych. 1990. A 22,000-year-old Middle Stone Age camp site with plant food remains from the north-eastern Cape. South African Archaeological Bulletin 45: 93-99. https://doi.org/10.2307/3887967

Pettitt, P.B. \& A.W.G. Pike. 2007. Dating European Palaeolithic cave art: progress, prospects, problems. Journal of Archaeological Method and Theory 14: 27-47. https://doi.org/10.1007/s10816-007-9026-4

Smits, L.G.A. 1983. Rock paintings in Lesotho: site characteristics. South African Archaeological Bulletin 38: 62-76. https://doi.org/10.2307/3888638

Van der Merwe, N.J., J.C. Sealy \& R. Yates. 1987. First accelerator carbon-14 date for pigment from a rock painting. South African Journal of Science 33: 56-57.

WADley, L. 1995. Review of dated Stone Age sites recently excavated in the eastern Free State, South Africa. South African Journal of Science 91: 574-79.

WALKer, N.J. 1995. Late Pleistocene and Holocene hunter-gatherers of the Matopos: an archaeological study of change and continuity in Zimbabwe. Uppsala: Societas Archaeologica Upsaliensis.

- 2009. Archaeological mitigation measures for the Thune Dam construction and associated works. Water resources consultants, report prepared for the Republic of Botswana, Ministry of Minerals, Energy and Water Resources.

Wendt, W.E. 1976. 'Art mobilier' from the Apollo 11 Cave, South West Africa: Africa's oldest dated works of art. South African Archaeological Bulletin 31: 5-11. https://doi.org/10.2307/3888265

Whitley, D.S. 1998. Cognitive neuroscience, shamanism and the rock art of Native California. Anthropology of Consciousness 9: 22-37. https://doi.org/10.1525/ac.1998.9.1.22

Received: 15 February 2016; Accepted: 12 May 2016; Revised: 17 August 2016

(C) Antiquity Publications Ltd, 2017 